See discussions, stats, and author profiles for this publication at: https://www.researchgate.net/publication/339829611

\title{
A primer of host-plant specialization in bees
}

Article in Emerging Topics in Life Sciences · March 2020

DOI: 10.1042/ETLS20190118

\section{CITATIONS}

11

3 authors, including:

Claus Rasmussen

Aarhus University

144 PUBLICATIONS 2,846 CITATIONS

SEE PROFILE

Some of the authors of this publication are also working on these related projects:

Native Danish bees - also in the future View project

Process of speciation in the Colletes succinctus group View project
READS

804

Nicolas J Vereecken

Université Libre de Bruxelles

271 PUBLICATIONS 1,856 CITATIONS

SEE PROFILE 


\title{
Review Article
}

\section{A primer of host-plant specialization in bees}

\author{
๑Claus Rasmussen ${ }^{1}$, $\odot$ Michael S. Engel ${ }^{2,3}$ and $\odot$ Nicolas J. Vereecken ${ }^{4}$ \\ ${ }^{1}$ Department of Bioscience, Aarhus University, Aarhus, Denmark; ${ }^{2}$ Division of Entomology, Natural History Museum, and Department of Ecology and Evolutionary Biology, \\ University of Kansas, Lawrence, KS, U.S.A; ${ }^{3}$ Division of Invertebrate Zoology, American Museum of Natural History, New York, NY, U.S.A; ${ }^{4}$ Agroecology Lab, Université libre de \\ Bruxelles (ULB), Boulevard du Triomphe CP 264/02, B-1050 Brussels, Belgium
}

Correspondence: Claus Rasmussen (claus.rasmussen@bios.au.dk)

Received: 13 December 2019 Revised: 17 February 2020 Accepted: 21 February 2020

Version of Record published: 10 March 2020
The bee-flower biological association is one of the most famous examples of insect-plant interactions, and it is axiomatic that these are of critical importance for sustaining thriving terrestrial ecosystems. Yet, the most familiar associations are often artificially managed agricultural ecosystems, reflecting an exceptionally narrow range of bee species (often only one) and a concomitantly restricted range of associated behaviors, morphologies, and mechanisms tied to pollination. Here we provide a brief account of the range of beefloral associations encompassing floral specialization in terms of diet, behavior, and morphology. These natural associations not only promote healthy ecosystems, but also can be integrated in sustainable ways for more efficient pollination of crops by targeting bee species whose diets, behaviors, and pollen-gathering structures evolved precisely to visit such floral species rather than less efficient, and often non-native, generalists that are otherwise exploited for such purposes.

\section{Introduction}

Flowering plants and bees often share a mutualistic relationship, where flowers provide bees with food and other floral rewards such as oils, fragrances, and resins [1], while bees bring about pollen transfer during their floral visits, contributing to the sexual reproduction and ultimate survival of their hosts. In this process, known as pollination, pollen grains are transferred from the male anther of a flower to the female stigma of flowers from the same species [2,3]. This exceedingly important aspect of angiosperm life history has been heralded as one of the principle factors contributing to the radiation and global success of flowering plants [4]. Estimates indicate that the proportion of modern-day animalpollinated flowering species ranges from a mean of $78 \%$ of the flowering plant species in temperatezone communities to $94 \%$ in tropical communities [5].

Beyond the pivotal contribution of pollinators for the survival and diversification of wild flowering plants, this plant-animal relationship is also particularly important from an ecosystem-services perspective. Globally, more than $75 \%$ of our main crop species rely on or benefit from animal pollination for increased yield [6]. Despite the importance of agricultural productivity [7], crop yields rarely reach their full potential in part due to inadequate pollination [8]. Studies have shown that small-scale agricultural farms with proper pollination increase their yields by an average of $24 \%$ [8]. However, a single, managed pollinator species, e.g. the western honey bee (Apis mellifera), is usually insufficient for increasing yield alone [9]. It is the diversity in body size, ecological traits, evolutionary histories, and behavior of pollinators that secure efficient pollination, rather than the sheer abundance of a single managed species $[10,11]$. In addition, pollination also improves crop quality, size, and shelf life, which are important for an increased final market price [12-14].

Here we provide a primer to host-plant specialization in bees in order to: revive interest in these sometimes unusual forms of ecological specialization; identify current needs in terms of research; and highlight the importance of these traits and their diversity at the local scale for the study of pollination biology relevant to all flowers, wild and cultivated. 


\section{Bee biology and foraging}

Bee nests usually consist of individual brood cells, each containing food provisions and a developing immature bee. The cells can be located in a vast variety of substrates, including (but not limited to) burrows in the soil, wood or plant pith, and even in empty snail shells $[15,16]$. Whether the bees build their own nest or they are kleptoparasites that usurp the nests of other bees, the offspring almost exclusively and invariably develop upon stored volumes of pollen, an essential source of proteins and sterols, and carbohydrates in the form of nectar. Pollen also provides lipids and other important nutrients for the bees [17]. Adults mostly feed on nectar and to a varying extent pollen $[15,18,19]$.

A number of bees either supplement or completely replace pollen protein in their diet. This includes the addition of floral lipids or oils [1,20], carrion [21], prey [22], vertebrate tears [23,24], and mold spores [25]. Lastly, recent research has shown that bees are omnivorous since they incidentally consume substantial quantities of microbes present in pollen. These microbial organisms are key to the overall fitness of the bees, and they underlie their health as adults as well as larval development [26-29].

Some bees, in particular eusocial species that maintain their colony year round, are generalist pollen foragers, or polylectic, with no apparently specialized plant associations. Other groups of bees have more specific pollen preferences, limited in range from one plant species only (strict monolectic), to plant species belonging to a couple or more genera in the same family (oligolectic), or across a narrow range of plant families (mesolectic) [30].

A limitation for bee-plant associations is the availability and spatial distribution of their food plants. Bees can only fly a certain distance from their nest to a food source. The distance is determined by body size $[31,32]$ and presumably their associated metabolic rate. Gathmann and Tscharntke [31] experimentally recorded that select bees travel 150-600 $\mathrm{m}$ for food, although it may be that the majority of individuals do not forage over long distances, with only a few individuals capable of flying in excess of $1100 \mathrm{~m}$ [33]. An implication of increased foraging distance for solitary bees is a higher cost on the production of offspring. For example, it was found that the number of brood cells provisioned per unit time decreased by $23 \%$ or more, at a meager increase in flight distance of $150 \mathrm{~m} \mathrm{[34].}$

Bees are not limited to native host plants. They are also frequently visiting exotic plants and therefore can move to and thrive in adventive locations, eventually establishing themselves. Several species of bumble bees (Bombus spp.) introduced for crop pollination to New Zealand in 1885 performed better there than within their native range. For example, Bombus ruderatus, once critically endangered [35] and now extinct [36] in native Denmark, is apparently abundant in New Zealand [37]. Other bees are inadvertently exotic [38], in particular those species that nest in stems or wood and are polylectic [39-42]. Oligolectic exotic species are also known, but they usually remain specialized on pollen hosts closely related to those visited in their native range [39].

The effectiveness of a bee as a pollinator depends on many factors. It is important to establish if pollen is collected and placed on the bee, and if the bee continues to forage and visit the same floral species where pollen can be deposited [43]. Bees that carry pollen internally or have only limited external pollen-collecting hairs, such as species in the genus Hylaeus (Figure 1D), will carry less pollen available for cross-pollination, as will species that carefully pack and store pollen on certain body parts that are less likely to come into contact with floral stigmas before returning to the nest. Some bees end up not touching the pollen-loaded anthers or fail to deposit pollen on receptive stigmas, thus preventing effective cross-pollination. Examples include species of Bombus (Figure 1F) and Xylocopa that are commonly observed biting through the base of the corolla to access the nectar (nectar robbing), without entering through the corolla, thus never contacting the anthers and stigma [44].

\section{Diet specialization}

Host specialization is widespread among herbivorous insects, yet the selective advantage leading to the evolutionary origin of foraging specializations among bees is not fully understood. General characteristics of flowers, such as bilateral symmetry (zygomorphy), have possibly evolved as adaptations to pollination by bees [2,3], although a more refined understanding of the Cretaceous pollinating insect-angiosperm co-radiations and discerning between correlations versus causes and effects remain obscure [45]. For example, the evidence is lacking that a switch from ancestral wasp carnivory to pollen-feeding led to the diversification of bees [46]. Although pollen consumption was a necessary but seemingly insufficient condition for their diversification, other complementary innovations such as a broadening of host-plant diet, perhaps allowed for the radiation of major bee lineages. Notwithstanding the role of pollenivory in defining the origin of bees, the radiation of bees 

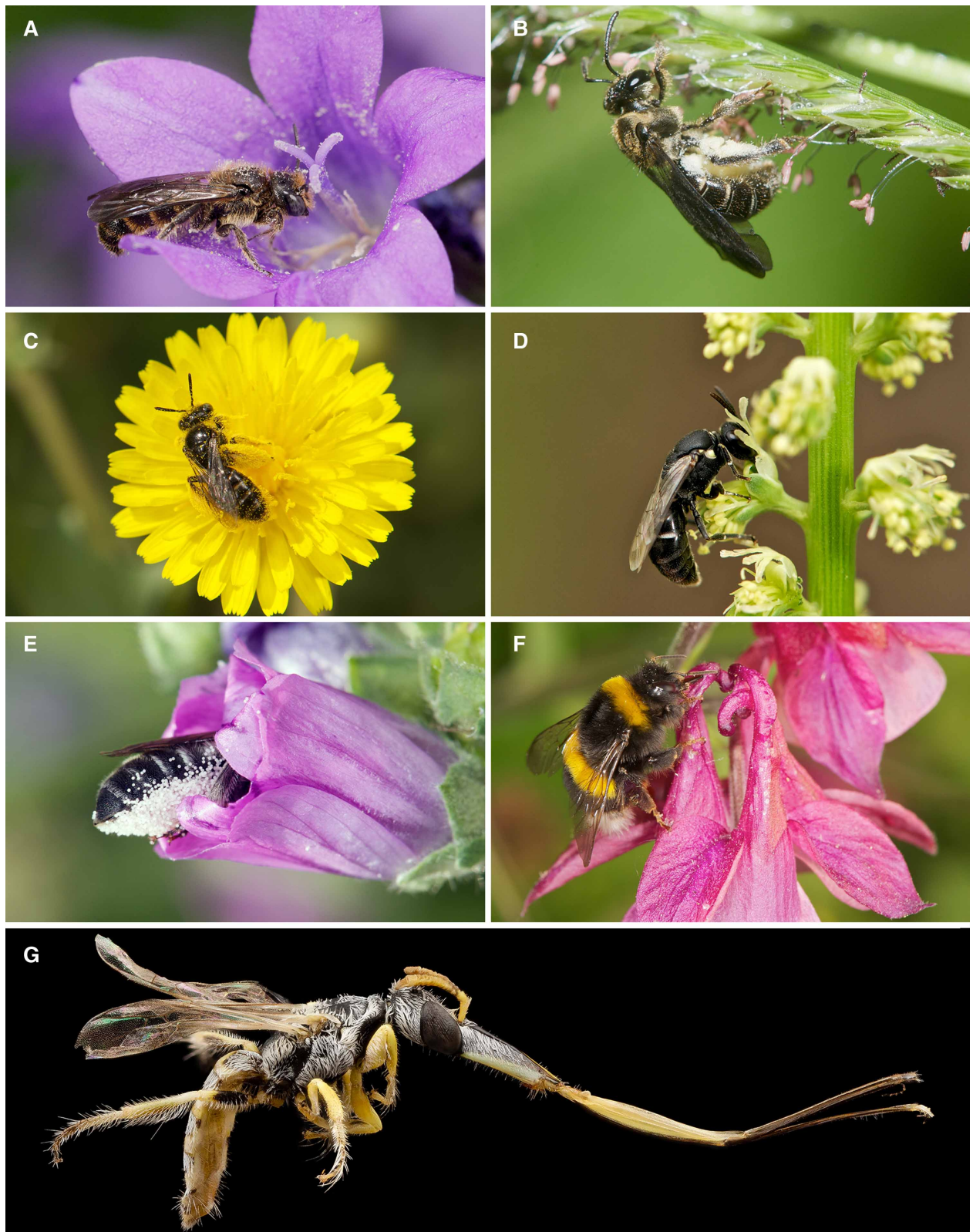

Figure 1. Pollen and nectar foraging bees.

Photos by N. Vereecken except were noted. (A) Chelostoma rapunculi (Megachilidae) on Campanula sp., Campanulaceae (Belgium); (B) Lipotriches clavatus (Halictidae) collecting pollen moistened by morning dew on Eleusine indica, Poaceae (DRCongo); (C) Panurgus sp. (Andrenidae) on Asteraceae (Sardinia, Italy); (D) Hylaeus signatus (Colletidae) a specialist on Reseda luteola, Resedaceae (Belgium), this genus transports pollen internally and has limited pubescence for retaining pollen externally; (E) Hoplitis cristatula (Megachilidae) on Malva sylvestris, Malvaceae (France), notice the pollen-loaded scopa on the metasoma; (F) Bombus terrestris (Apidae) nectar robbing on Aquilegia sp., Ranunculaceae (Belgium); (G) Geodiscelis longiceps (Colletidae) specialized on Crinklemat plants (Tiquilia) (Chile) (photograph by Sam Droege).

should not be conceptualized as a single, Cretaceous-aged event tied to flowering plants. Instead, bee diversity is the result of numerous, individual radiations within the various lineages that undoubtedly took place at different times throughout bee evolution and as a result of unrelated biotic and abiotic factors. Future research should explore the extent to which host-plant shifts may have fueled the diversification of wild bees in groups 
dominated by oligolectic species or species that are associated with particular floral morphologies, but avoid the pitfalls of over simplifying evolutionary processes by assuming accelerated change after 'key innovations' or arriving at an 'adaptive zone' e.g. [47]. Such work should be undertaken at a finer taxonomic scale, ideally at the level of species as it is at this level at which evolutionary processes unfold.

The protein content in pollen ranges from $2.5 \%$ to $61 \%$, with most of the proteins being enzymes that function during pollen-tube growth and subsequent fertilization, but the specific protein content may be what drives floral host choice [48]. Because the attractive nutrients are encapsulated inside the highly resistant pollen grain and only available after a lengthy digestive process [17,49], pollen quality cannot be assessed in situ while foraging. Recognition of plants is typically based on visual and olfactory cues and signals, i.e. through peculiarities in the composition of floral volatiles [50]. By limiting foraging to a smaller number of closely related host plants, bees can ensure that the provisions are of a constant and known protein quality. Variable quality may provide inadequate energy for growth and even cause larval death $[48,51]$, but research in this field targeting wild, solitary bees is still limited.

While specialization may seem like an evolutionary dead-end, diet breadth is in fact labile with frequent shifts in, e.g. Andrena (Callandrena), Chelostoma, and Diadasia from an oligolectic ancestor to descendants foraging across a broad range of pollen sources [52-54]. At the same time, rather highly conserved floral specializations within different clades of Chelostoma (Figure 1A), the exploitation of unrelated hosts with close floral similarity, as well as poor larval development on non-host pollen collectively suggest that floral host choice may still be constrained physiologically or neurologically within oligolectic bees [53,55]. Evidence from European species of Colletes indicates that an 'invisible' specialization might be driven by pollen chemistry - bees can be specialized on patterns of sterols and amino acids, and evolutionary shifts to morphologically contrasting host plants are facilitated by similarities in pollen chemistry rather than plant phylogenetic relatedness or morphological affinities [56].

How many bees are specialized on pollen sources? To a degree that they can only raise their larvae on pollen from a limited number of plant families or plant genera, Michener [15] refers to 69 of 443 genera in six bee families, corresponding to a global average of $\sim 9 \%$ based on his numbers [1491/17187] of all bee species that are oligolectic. Specialization is not equally distributed across the globe, with the fewest specialists in tropical and high-latitude regions. Moldenke [57] reported the highest proportion of specialist pollen collectors as 60\% among desert species and 50\% in the Mediterranean-like climate areas of California. Westrich [58] recorded $30 \%$ of German bee species were specialists, while towards higher latitudes in boreal areas of Scandinavia $<20 \%$ are oligolectic [59].

Although specialist bees are somewhat phylogenetically restricted, i.e. certain tribes or subfamilies encompass species that tend to have more restricted floral choices, specialists are still found in virtually every lineage of bees. Host plant specialization is particularly common among the following taxonomic groups: Euryglossinae and several groups of Paracolletinae (Colletidae); Panurginae (Figure 1C) and some Andreninae (Andrenidae); most Rophitinae (Halictidae); most Melittidae; many Fideliinae and some Lithurginae and Megachilinae (Figure 1E) (Megachilidae); some Eucerini and most Ancylaini, Tarsaliini, and Emphorini (Apidae) [15,16,60]. Nonetheless, while useful in a descriptive sense, such broad ecological generalizations hold the potential to obscure finer-scale distinctions and lead to false positives or uninformative tests e.g. [47]. For example, it is important to note that many polylectic species at a local or short temporal scale have a functionally narrow diet range [61].

Plants in $\sim 34$ different plant families are more often the pollen source for specialized bees, among which Asteraceae, Myrtaceae, and Convolvulaceae each have more than 100 associated specialist bee species [15]. Other plant families have a lower total number of associated specialist bees, although they may all at the same time host a wide range of polylectic bee species. Plant families with just a single recorded oligolectic bee include Niltonia virgilii (Colletidae) visiting Bignoniaceae (Jacaranda puberula) [62], Neffapis longilingua (Andrenidae) visiting Malesherbiaceae (Malesherbia) [63], and Anthemurgus passiflorae (Andrenidae) visiting Passifloraceae (Passiflora lutea) [64]. The only oligolectic visitors to Hydrangeaceae (Philadelphus) are two disjunct species of Chelostoma, from North America and China, indicating a floral host choice that might have been conserved for several million years [53]. True monolecty is exceedingly rare and described as 'oligolecty without a choice' because it is often assumed that a bee specialized on a single plant species could also visit other closely related, morphologically similar, flowering plants whenever the latter would be available [30]. An apparent exception to this case is Flavipanurgus venustus (Andrenidae), a European species found in Mediterranean climates that consistently visits Cistus crispus (Cistaceae) across space (18 sites in SW Iberian 
Peninsula) and time (three consecutive years) despite the presence of closely related congeneric plant species whose flowers are morphologically similar [65].

\section{Behavioral specialization}

Evolutionary adaptations to flower foraging are not only limited to structural modifications. As suggested by Mayr [66], the invasion of any new niche presents a range of new selective pressures that will lead to a change in behavior. Therefore, initial behavioral specializations may lead to subsequent structural changes, and thus act as a pacemaker for evolution. If this is the case, then it is critical to first look at behavioral specialization for pollen and nectar gathering by bees among other floral rewards. While structural specializations are more straightforward to identify, behavioral specialization is often subtle and requires in-depth field studies.

Linsley [67], while meticulously documenting how desert bees operate under harsh climatic conditions, noted that pollen collection primarily occurs from dawn and to the period before or just after sunrise, or at least late afternoon, when flowering plants in the genera Mentzelia (Loasaceae) and Oenothera (Onagraceae) release their pollen. This author also noted that of those bees active during the heat of the day, the majority were small-bodied and thus able to avoid sun exposure by entering flowers and remaining partly shaded. Bees' thermal tolerances may play a critical role in determining specific niche parameters including the timing of foraging bouts.

Although the timing of pollen collection is key to optimizing foraging, the ability of bees to moisten the pollen they collect may also play a critical role in the completion of their life cycle. For bees that either possess limited scopal hairs or bees that collect tiny pollen grains (e.g. from Boraginaceae or Poaceae), the foraging flight back to the nest can be made more efficient by packing up larger volumes of pollen through the active moistening of pollen grains with nectar, oil, saliva, or morning dew (Figure 1B). This behavioral adaptation allows for a larger and wider variety of pollen grains with different sizes and surface ornamentation to be transported by the same individual bee [68]. While wetting pollen may improve efficiency in pollen transport, it may also reduce the effectiveness of such pollen to be transferred to stigmas, thereby decreasing pollination efficiency.

While these specializations, timing and packing, can be found across different bee lineages, other behavioral adaptations are specific to certain lineages. Most gardeners know the sound produced by bees when pollinating plants in the family Solanaceae, and it is the sound of fruits to come. Pollen in most flowering plants are exposed and made available when the floral anthers split. However, in some plants the anthers do not split, but are instead poricidally dehiscent [69]. Buchmann [69] described the behavior, involving only the use of flight muscles for buzzing [also called sonication], as: 'Upon alighting, female bees curl around the 'anther cone,' if present or grasp clusters of stamens while rapidly shivering their large indirect flight muscles. This produces an audible buzzing sound and transmits strong vibrations to the floral androecium. In response to this vibration, the pollen is expelled striking and sticking to the venter of the bee where it is later groomed and packed into the scopa'. The night-shade family of Solanaceae is the best known of the families with poricidally dehiscent anthers, but such anthers are found in $\sim 9 \%$ of all flowering plant species. The western honey bee (A. mellifera) is unable to vibrate its thoracic muscles and worker honey bees are usually regarded as poor pollinators of 'buzz' flowers. Their hives are therefore only placed in blueberry fields requiring buzzing because the high number of visits to the flowers compensates for the lack of specialization in behavior and low per capita pollination efficiency [70]. In contrast, bumble bees (Bombus) and certain members of the families Colletidae, Halictidae, and Apidae can 'buzz'. Members of Megachile and Andrenidae, except Protandrena, Protoxaea, Alocandrena and certain members of Andrena, are apparently unable to 'buzz' anthers $[69,71-76]$.

An important behavioral aspect of adaptation relates to the phenological timing of the adult bee flight. In areas with a marked seasonality, adults are often only found in flight during specific dates, during either spring, summer or fall. As has been outlined in the phenological match-mismatch hypothesis, climate warming may cause different emergence patterns for plants and pollinators, with marked effects on phenology, demography, local abundance, and large-scale distribution of plants and pollinators [77]. Such mismatch may influence specific plant associations, although the large-scale implications are as of yet unknown [78-84]. Climatic warming may also result in the local exclusion and potential extirpation of bees with limited thermal tolerances. 


\section{Morphological specialization}

Most foraging specialization has to do with pollen gathering, as it is the pollen sources that are restricted, while nectar preference is more general. Despite this, some bees also exhibit specialization towards nectar collecting. In one bee species from Brazil, the short-tongued colletid Niltonia virgilii, Laroca, Michener, and Hofmeister [62] discovered that the labial palpi were extremely modified, formed as an elongate tube, approaching the body length of the species, and augmented to imbibe nectar from Jacaranda puberula (Bignoniaceae) [62]. Other shorttongued colletids with modified mouthparts, achieved via an expanded head-length, include Geodiscelis from Chile and Peru (Figure 1G), that are specialized on nectar from Boraginaceae [85]. In fact, it may be that elongateheaded bees, which occur across various groups (e.g. Thrinchostoma, Chlerogas, Chlerogella, Ischnomelissa, Chlerogelloides), are specialized for particular floral morphologies and nectar rather than specific sources of pollen, although for most their biology remains to be discovered [86].

The external structures for the transport of pollen by the female bee from the flowers back to the nest can be classified under two broad and general categories: (1) scopae for areas of long, frequently dense hairs, usually on the underside of the metasoma, the hind legs, or the propodeal sides of many Andrena, where pollen is entangled, and (2) fiscinae and corbiculae with fringes of hairs enclosing a space in which the pollen is carried [87-89]. In the latter, pollen are often packed moistened, while the arrangement of the scopa depends on the pollen type collected.

The density and plumosity of scopal hairs are presumably related to the size and structure of the pollen grains. Pollen sizes vary from $<10 \mu \mathrm{m}$ to more than $100 \mu \mathrm{m}$, and come in a plethora of spherical morphologies, sometimes held together by viscin threads, and enclosed by an outer exine layer and an inner intine layer [90]. The ornamentation is specific to different plant taxa, sometimes at the species level, and is extremely variable. Examples include (but are not limited to) species of Eucerini that have independently evolved specialization (i.e. oligolecty) on Malvaceae which produce remarkably large pollen grains; the scopae of female bees exhibit significantly larger spaces among individual scopal hairs than in closely related species visiting host plants in other families [91]. Differences in scopal hair densities resulting in more 'closed' versus 'open' scopae have been observed in various bee lineages, e.g. [92], but remain to be more fully explored. However, as a general rule it seems that large pollen grains can therefore only efficiently be collected and transported by bees with stout, unbranched scopal hairs, such as those found in the genus Xenoglossa (Apidae) specialized on pollen from gourds and squashes and Andrena (Onagrandrena) on Onagraceae [68,93]. This phenomenon is further documented by examining morphological specializations of bees tied to particular host plants with unusually small pollen grains: for example, while examining pollen loads from different bees, researchers found that scopal hairs on the hind legs of bees that collect small pollen grains, like Ptiloglossa and Caupolicana (Colletidae), have an extraordinary fluffy appearance, increasing the effectiveness of picking up extremely small particles [93,94]. Similar scopal hairs, with a dense network of multi-branched hairs, are also found in the family Andrenidae (Oxaea) [93]. Other bees possess smoother, more numerous, and slender hairs with many closely spaced branches in a scopal network. Once the pollen grain size reaches above $100 \mu \mathrm{m}$, most bees are unable to pack and force the large pollen grains into the network of branched hairs for transport [93].

A morphological specialization for extracting and transporting pollen involves the presence of modified, long hairs, usually hooked or waxy at the tips, near the mouthparts or on the proboscis, on the forelegs, or even on the vertex $[68,95,96]$. This allows bees to extract pollen from anthers located deep in a narrow corolla and are features that occur in various unrelated bee genera and families [97,98], such as in different species of Apidae collecting pollen from flowers of Pontederiaceae [99].

A distinct challenge for bees is the collection and transportation of floral oils. It has been known since Vogel [100] that solitary female oil bees collect fatty floral oils from specialized oil-secreting plants with the aid of specialized hairs on either their legs or abdomen, a reward used as food for their larvae and/or to line their brood cells. Branched hairs to restrain the oil have evolved independently in several different lineages of bees [93,101]: Macropis (Melittidae) collect floral oils from species in the family Primulaceae in the northern temperate regions of the Old and the New World (Figure 2A) [102]; Rediviva (Melittidae) in Africa from representatives in the Scrophulariaceae and Orchidaceae [102], while Ctenoplectrini (Apidae) collect oils from species of Cucurbitaceae in Borneo, Sumatra, Java, and Sulawesi and possibly also in Africa [103]; in the New World tropics, Centris, Epicharis, and Chalepogenus (Apidae) are some of the best known oil-gathering bees from taxa in the families Malphighiaceae and Scrophulariaceae. 

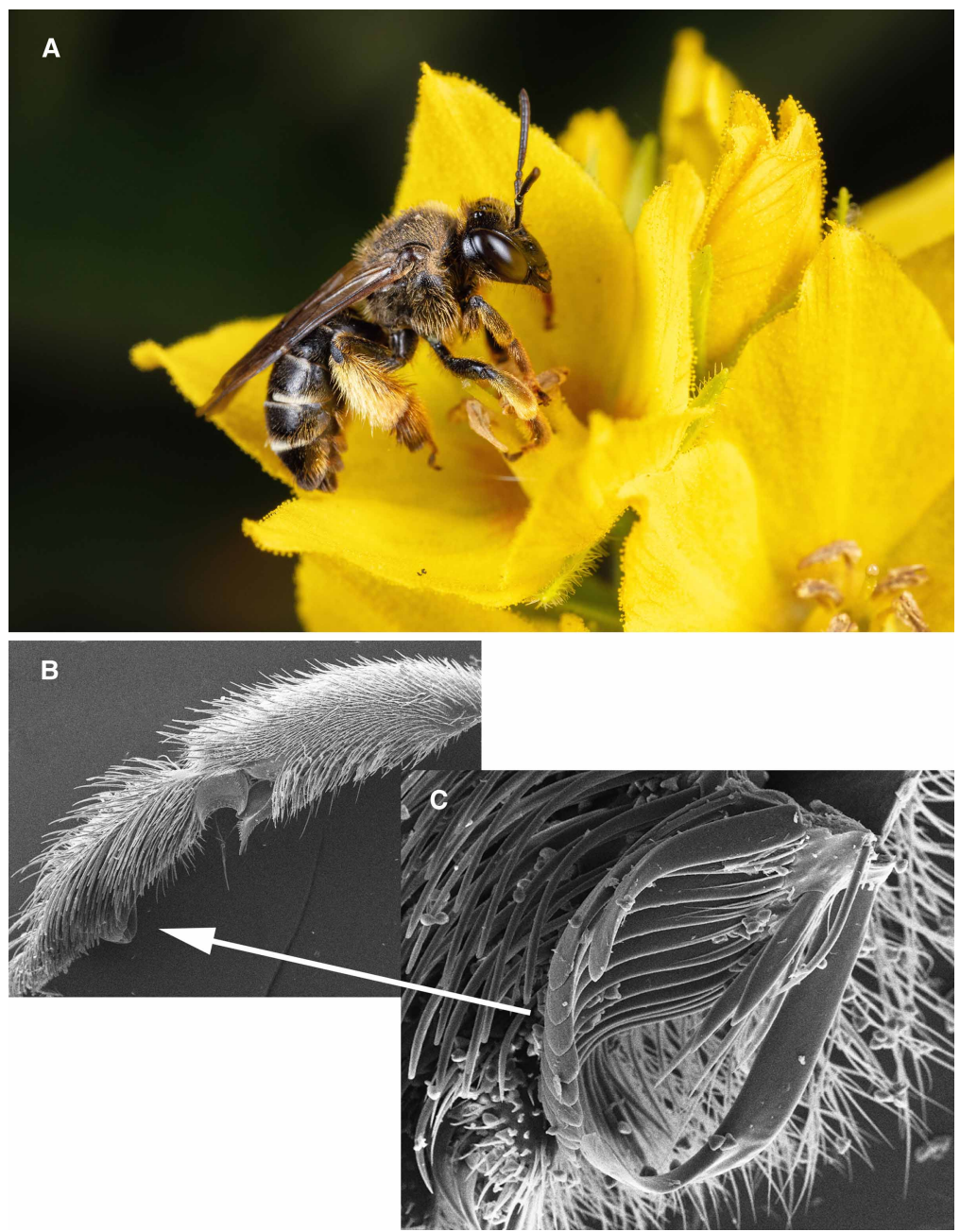

Figure 2. Oil bees and oil-flowers.

(A) A female of the oil-collecting bee Macropis fulvipes (Melittidae) foraging for floral oils on Lysimachia sp., Primulaceae (Belgium), photograph by N. Vereecken; (B) Foreleg of Centris neffi (Apidae) (Peru), an oil-collecting specialist from Calceolaria, Scrophulariaceae with modified setae on the basitarsus; (C). Closeup and frontal view of the same species, with the comb on the left and the few giant spatulate setae on the right, in the middle the stout setae that may serve to open the floral oil-glands, the elaiophores (SEM image by Claus Rasmussen).

As an example of this morphological specialization, most species of Centris collect floral oils with modified setae on the fore- and midlegs (Figure 2B,C) [101,104,105]. The female foreleg typically includes a row of 30 to 40 enlarged, flattened, and apically curved setae - the comb - on the basitarsus. The curved setae overlap slightly and, depending on the size of the bee, measure from $0.6 \mathrm{~mm}$ to $2.1 \mathrm{~mm}$ in length [104]. Opposite to the foreleg comb is a series of two to five giant spatulate setae, forming, together with the comb, the 'kaputzorgane' (sensu [20]). These latter setae are only found within females of Centris, although it is not clear whether these serve to collect oil more efficiently when appressed to the surface of the elaiophore. That is, the giant spatulate setae extend the scraping margin, thus increasing the oil-uptake rate by forming a continuation of the scraping movement, when the individual setae of the primary comb bend over [104]. Between the giant setae and, or just posterior to, the comb, a series of up to three stout setae is found, the setae may be large and hooked inward [104]. In some species, similar setae are found also on the midleg. It has been hypothesized that the stout setae may serve to open the cuticula of the epithelial elaiophores by ripping it up [104]. Furthermore, many species of Centris have a smaller and shorter compound comb anterior to the primary one [104]. The above-described comb pattern is found on most Centris, and on virtually all that are known to collect oil from epithelial 
elaiophores. Modifications in other groups of oil-gathering bees include a dense pad that is used to sop up oil, while the comb is more or less reduced [106].

Naturally, the bee-flower biological association is much more diverse than highlighted herein, but the above overview serves as a brief account of the range of associations encompassing bee-floral specialization in terms of diet, behavior, and morphology.

\section{Summary}

- Bee-mediated pollination is one of the most fundamental and vital functions in healthy terrestrial ecosystems and yet remains poorly appreciated.

- Diet specialization, bees foraging only from a narrow range of pollen sources, secure larval provisions with optimal protein quality for growth.

- Behavioral specializations may act as a pacemaker of evolution, and frequently include daily timing of floral visits, moistening and packing of pollen grains for return flights to the nest, or the vibration of flowers (buzzing) for an effective release of pollen grains.

- Morphological specialization includes both the density and type of hair for collection of different sized of pollen grains, flattened spatulate hairs for gathering oil, and extremely elongate mouthparts to gain access to hidden nectar sources.

- Future work should further explore the behavior, physiology, and morphology of a greater breadth of individual bee species in association with their floral hosts, and give precedence to understanding host shifts at the operational level of species relative to broader, coarsely characterized ecological generalizations at higher taxonomic ranks.

- A promising avenue for future research into the evolution of host plants by bees relates to the impact of host plant shifts on diversification rates in different groups of wild bees.

\section{Competing Interests}

The authors declare that there are no competing interests associated with the manuscript.

\section{Funding}

N.J.V. received financial support from the FNRS/FWO joint programme "EOS - Excellence Of Science" for the project and "CliPS: Climate change and its impact on Pollination Services (project 30947854)" during the preparation of this article. M.S.E. was partly supported by U.S. National Science Foundation (grant DBI-1057366).

\section{Author Contribution}

C.R. drafted and contributed to the manuscript, M.S.E. and N.J.V. contributed to the manuscript.

\section{Acknowledgements}

The authors are grateful to two anonymous reviewers for their input on an earlier draft of the manuscript, and to the editors for inviting us to contribute this brief review.

\section{References}

1 Simpson, B.B. and Neff, J.L. (1981) Floral rewards: alternatives to pollen and nectar. Ann. Mo. Bot. Gard. 68, 301-322 https://doi.org/10.2307/ 2398800

2 Proctor, M.C.F. and Yeo, P.F. (1979) The Pollination of Flowers, Collins, London

3 Proctor, M.C.F., Yeo, P.F. and Lack, A.J. (1996) The Natural History of Pollination, Timber Press, Portland, OR 
4 Neff, J.L. and Simpson, B.B. (1993) Bees, pollination systems and plant diversity. In Hymenoptera and Biodiversity (La Salle, J. and Gauld, I.D., eds), pp. 143-167, CAB International, Wallingfood

5 Ollerton, J., Winfree, R. and Tarrant, S. (2011) How many flowering plants are pollinated by animals? Oikos 120, 321-326 https://doi.org/10.1111/j. 1600-0706.2010.18644.x

6 Klein, A.-M., Vaissière, B.E., Cane, J.H., Steffan-Dewenter, I., Cunningham, S.A., Kremen, C. et al. (2007) Importance of pollinators in changing landscapes for world crops. Proc. R. Soc. Lond. Ser. B 274, 303-313 https://doi.org/10.1098/rspb.2006.3721

7 Gallai, N., Salles, J.-M., Settele, J. and Vaissièrea, B.E. (2009) Economic valuation of the vulnerability of world agriculture confronted with pollinator decline. Ecol. Econ. 68, 810-821 https://doi.org/10.1016/j.ecolecon.2008.06.014

8 Garibaldi, L.A., Carvalheiro, L.G., Vaissiere, B.E., Gemmill-Herren, B., Hipolito, J., Freitas, B.M. et al. (2016) Mutually beneficial pollinator diversity and crop yield outcomes in small and large farms. Science 351, 388-391 https://doi.org/10.1126/science.aac7287

9 Garibaldi, L.A., Steffan-Dewenter, I., Winfree, R., Aizen, M.A., Bommarco, R., Cunningham, S.A. et al. (2013) Wild pollinators enhance fruit set of crops regardless of honey bee abundance. Science 339, 1608-1611 https://doi.org/10.1126/science.1230200

10 Klein, A.-M., Steffan-Dewenter, I. and Tscharntke, T. (2003) Fruit set of highland coffee increases with the diversity of pollinating bees. Proc. R. Soc. Lond. Ser. B 270, 955-961 https://doi.org/10.1098/rspb.2002.2306

11 Woodcock, B.A., Garratt, M.P.D., Powney, G.D., Shaw, R.F., Osborne, J.L., Soroka, J. et al. (2019) Meta-analysis reveals that pollinator functional diversity and abundance enhance crop pollination and yield. Nat. Commun. 10, 1481 https://doi.org/10.1038/s41467-019-09393-6

12 Klatt, B.K., Holzschuh, A., Westphal, C., Clough, Y., Smit, I., Pawelzik, E. et al. (2014) Bee pollination improves crop quality, shelf life and commercial value. Proc. R. Soc. B Biol. Sci. 281, $20132440 \mathrm{https}: / /$ doi.org/10.1098/rspb.2013.2440

13 Gajc-Wolska, J., Kowalczyk, K., Mikas, J. and Drajski, R. (2011) Efficiency of cucumber (Cucumis sativus L.) pollination by bumblebees (Bombus terrestris). Acta Sci. Pol. Hortorum Cultus 10, 159-169

14 Al-Attal, Y.Z., Kasrawi, M.A. and Nazer, I.K. (2003) Influence of pollination technique on greenhouse tomato production. Agric. Mar. Sci. 8, 21-26

15 Michener, C.D. (2007) The Bees of the World, second edition, Johns Hopkins University Press, Baltimore

16 Danforth, B.N., Minckley, R.L. and Neff, J.L. (2019) The Solitary Bees: Biology, Evolution, Conservation, Princeton University Press

17 Dobson, H.E.M. and Peng, Y.-S. (1997) Digestion of pollen components by larvae of the flower-specialist bee Chelostoma florisomne (Hymenoptera: Megachilidae). J. Insect Physiol. 43, 89-100 https://doi.org/10.1016/S0022-1910(96)00024-8

18 Cane, J.H. (2016) Adult pollen diet essential for egg maturation by a solitary Osmia bee. J. Insect Physiol. 95, 105-109 https://doi.org/10.1016/j. jinsphys.2016.09.011

19 Cane, J.H., Dobson, H.E.M. and Boyer, B. (2017) Timing and size of daily pollen meals eaten by adult females of a solitary bee (Nomia melander) (Apiformes: Halictidae). Apidologie 48, 17-30 https://doi.org/10.1007/s13592-016-0444-8

20 Vogel, S. (1974) Ölblumen und ölsammelnde Bienen. Trop. Subtrop. Pflwelt 7, 1-267

21 Roubik, D.W. (1982) Obligate necrophagy in a social bee. Science 217, 1059-1060 https://doi.org/10.1126/science.217.4564.1059

22 Mateus, S. and Noll, F.B. (2004) Predatory behavior in a necrophagous bee Trigona hypogea (Hymenoptera; Apidae, Meliponini). Naturwissenschaften 91, 94-96 https://doi.org/10.1007/s00114-003-0497-1

23 Bänziger, H. (2018) Congregations of tear drinking bees at human eyes: foraging strategies for an invaluable resource by Lisotrigona in Thailand (Apidae, Meliponini). Nat. Hist. Bull. Siam Soc. 62, 161-193

24 Bänziger, H., Boongird, S., Sukumalanand, P. and Bänziger, S. (2009) Bees (Hymenoptera: Apidae) that drink human tears. J. Kans. Entomol. Soc. 82, 135-150 https://doi.org/10.2317/JKES0811.17.1

25 Blagoveshchenskaya, N. N. (1995) Гнездование Macropis labiata F. (Аpoidea, Melittidae) в Среднем Поволжье ТThe nesting of Macropis labiata F. (Apoidea, Melittidae) in the Middle Volga basin]. In: Naumov RV (ed) Любищевские чтения, 1995 г. (Тезисы докладов) The Reading to the Memory of Prof. A. A. Lyubishchev]. Ульяновский государственный педагогический институт, Ulyanovsk, Russia, pp 47-48

26 Steffan, S.A. and Dharampal, P.S. (2019) Undead food-webs: Integrating microbes into the food-chain. Food Webs 18, e00111 https://doi.org/10.1016/ j.fooweb.2018.e00111

27 Steffan, S.A., Dharampal, P.S., Danforth, B.N., Gaines-Day, H.R., Takizawa, Y. and Chikaraishi, Y. (2019) Omnivory in bees: elevated trophic positions among all major bee families. Am. Nat. 194, 414-421 https://doi.org/10.1086/704281

28 Steffan, S.A., Chikaraishi, Y., Currie, C.R., Horn, H., Gaines-Day, H.R., Pauli, J.N. et al. (2015) Microbes are trophic analogs of animals. Proc. Natl Acad. Sci. U.S.A. 112, 15119-15124 https://doi.org/10.1073/pnas.1508782112

29 Dharampal, P.S., Carlson, C., Currie, C.R. and Steffan, S.A. (2019) Pollen-borne microbes shape bee fitness. Proc. R. Soc. B Biol. Sci. 286, 20182894 https://doi.org/10.1098/rspb.2018.2894

30 Cane, J.H. and Sipes, S.D. (2006) Characterizing floral specialization by bees: analytical methods and a revised lexicon for oligolecty. In Plant-pollinator Interactions: From Specialization to Generalization (Waser, N.M. and Ollerton, J., eds), pp. 99-122, University of Chicago Press, Chicago

31 Gathmann, A. and Tscharntke, T. (2002) Foraging ranges of solitary bees. J. Anim. Ecol. 71, 757-764 https://doi.org/10.1046/j.1365-2656.2002. $00641 . x$

32 Greenleaf, S.S., Williams, N.M., Winfree, R. and Kremen, C. (2007) Bee foraging ranges and their relationship to body size. Oecologia 153, 589-596 https://doi.org/10.1007/s00442-007-0752-9

33 Zurbuchen, A., Landert, L., Klaiber, J., Müller, A., Hein, S. and Dorn, S. (2010) Maximum foraging ranges in solitary bees: only few individuals have the capability to cover long foraging distances. Biol. Conserv. 143, 669-676 https://doi.org/10.1016/j.biocon.2009.12.003

34 Zurbuchen, A., Cheesman, S., Klaiber, J., Müller, A., Hein, S. and Dorn, S. (2010) Long foraging distances impose high costs on offspring production in solitary bees. J. Anim. Ecol. 79, 674-681 https://doi.org/10.1111/j.1365-2656.2010.01675.x

35 Madsen, H.B. (2009) Humlebier. In Den Danske Rødliste, Aarhus, Fagdatacenter for Biodiversitet og Terrestrisk Natur (B-FDC) (Wind, P., ed.), Aarhus Universitet, Danmarks Miljøundersøgelser

36 Madsen, H.B. (2019) Bier. In Den Danske Rødliste 2019 (Moeslund, J.E., Nygaard, B., Erjnæs, R., Bell, N., Bruun, L.D., Bygebjerg, R. et al., eds), Aarhus Universitet, DCE - Nationalt Center for Miljø og Energi, Aarhus

37 Donovan, B.J. (2007) Apoidea (Insecta: Hymenoptera), Manaaki Whenua Press, Lincoln, New Zealand

38 Russo, L. (2016) Positive and negative impacts of non-native bee species around the world. Insects 7, 1-22 https://doi.org/10.3390/insects7040069 
39 Cane, J.H. (2003) Exotic non-social bees (Hymenoptera: Apoidea) in North America: Ecological implications. In For Non-Native Crops, Whence Pollinators of the Future? (Strickler, K.L. and Cane, J.H., eds), pp. 113-126, Thomas Say Publications, Entomological Society of America, Lanham, Maryland

40 Andrieu-Ponel, V., Ponel, P., Féon, V.L., Geslin, B. and Duvallet, G. (2018) À propos du comportement de butinage de Megachile sculpturalis Smith, 1853, en France méditerranéenne (Nîmes et Montpellier) (Hymenoptera, Megachilidae). Bull. Soc. Entomol. Fr. 123, 49-54 https://doi.org/10.32475/ bsef_1984

41 Vereecken, N.J. and Barbier, E. (2009) Premières données sur la présence de l'abeille asiatique Megachile (Callomegachile) sculpturalis Smith (Hymenoptera, Megachilidae) en Europe. Osmia 3, 4-6

42 Rasmussen, C., Carríon, A.L., Castro-Urgal, R., Chamorro, S., Gonzalez, V.H., Griswold, T.L. et al. (2012) Megachile timberlakei Cockerell (Hymenoptera: Megachilidae): yet another adventive bee species to the Galápagos Archipelago. Pan-Pacific Entomol. 88, 98-102 https://doi.org/10.3956/2012-04.1

43 Kevan, P.G. and Baker, H.G. (1983) Insects as flower visitors and pollinators. Annu. Rev. Entomol. 28, 407-453 https://doi.org/10.1146/annurev.en.28. 010183.002203

44 Rojas-Nossa, S.V., Sánchez, J.M. and Navarro, L. (2016) Nectar robbing: a common phenomenon mainly determined by accessibility constraints, nectar volume and density of energy rewards. Oikos 125, 1044-1055 https://doi.org/10.1111/oik.02685

45 Grimaldi, D.A. (1999) The co-radiations of pollinating insects and angiosperms in the Cretaceous. Ann. Mo. Bot. Gard. 86, 373-406 https://doi.org/10. 2307/2666181

46 Murray, E.A., Bossert, S. and Danforth, B.N. (2018) Pollinivory and the diversification dynamics of bees. Biol. Lett. 14, 20180530 https://doi.org/10. 1098/rsbl.2018.0530

47 Franz, N.M. and Engel, M.S. (2010) Can higher-level phylogenies of weevils explain their evolutionary success? A critical review. Syst. Entomol. 35 597-606 https://doi.org/10.1111/j.1365-3113.2010.00534.x

48 Roulston, T.H., Cane, J.H. and Buchmann, S.L. (2000) What governs protein content of pollen: pollinator preferences, pollen-pistil interactions, or phylogeny? Ecol. Monogr. 70, 617-643 https://doi.org/10.1890/0012-9615(2000)070[0617:WGPCOP]2.0.C0;2

49 Bolick, M.R. and Vogel, S. (1992) Breaking strengths of pollen grain walls. Plant Syst. Evol. 181, 171-178 https://doi.org/10.1007/BF00937442

50 Dötterl, S. and Vereecken, N.J. (2010) The chemical ecology and evolution of bee-flower interactions: a review and perspectives. Can. J. Zool. 88, 668-697 https://doi.org/10.1139/Z10-031

51 Wcislo, W.T. and Cane, J.H. (1996) Floral resource utilization by solitary bees (Hymenoptera: Apoidea) and exploitation of their stored foods by natural enemies. Annu. Rev. Entomol. 41, 257-286 https://doi.org/10.1146/annurev.en.41.010196.001353

52 Larkin, L.L., Neff, J.L. and Simpson, B.B. (2008) The evolution of a pollen diet: host choice and diet breadth of Andrena bees (Hymenoptera: Andrenidae). Apidologie 39, 133-145 https://doi.org/10.1051/apido:2007064

53 Sedivy, C., Praz, C.J., Müller, A., Widmer, A. and Dorn, S. (2008) Patterns of host-plant choice in bees of the genus Chelostoma: the constraint hypothesis of host-range evolution in bees. Evolution 62, 2487-2507 https://doi.org/10.1111/j.1558-5646.2008.00465.x

54 Sipes, S.D. and Tepedino, V.J. (2005) Pollen-host specificity and evolutionary patterns of host switching in a clade of specialist bees (Apoidea: Diadasia) Biol. J. Linn. Soc. 86, 487-505 https://doi.org/10.1111//.1095-8312.2005.00544.x

55 Praz, C.J., Müller, A. and Dorn, S. (2008) Specialized bees fail to develop on non-host pollen: do plants chemically protect their pollen? Ecology $\mathbf{8 9}$, 795-804 https://doi.org/10.1890/07-0751.1

56 Vanderplanck, M., Vereecken, N.J., Grumiau, L., Esposito, F., Lognay, G., Wattiez, R. et al. (2017) The importance of pollen chemistry in evolutionary host shifts of bees. Sci. Rep. 7, 43058 https://doi.org/10.1038/srep43058

57 Moldenke, A.R. (1976) Evolutionary history and diversity of the bee faunas of Chile and pacific North America. Wasmann J. Biol. 34, 147-178

58 Westrich, P. (1990) Die Wildbienen Baden-Württembergs. Teil 1: Lebensräume, Verhalten, Ökologie und Schutz, Ulmer, Stuttgart

59 Pekkarinen, A. (1998) Oligolectic bee species in Northern Europe (Hymenoptera, Apoidea). Entomol. Fennica 8, 205-214 https://doi.org/10.33338/ef.83945

60 Michez, D., Eardley, C.D., Timmermann, K. and Danforth, B.N. (2010) Unexpected polylecty in the bee genus Meganomia (Hymenoptera: Apoidea: Melittidae). J. Kans. Entomol. Soc. 83, 221-230 https://doi.org/10.2317/JKES0911.20.1

61 Maclvor, J.S., Cabral, J.M. and Packer, L. (2014) Pollen specialization by solitary bees in an urban landscape. Urban Ecosyst. 17, 139-147 https://doi. org/10.1007/s11252-013-0321-4

62 Laroca, S., Michener, C.D. and Hofmeister, R.M. (1989) Long mouthparts among 'short-tongued' bees and the fine structure of the labium in Niltonia (Hymenoptera, Colletidae). J. Kans. Entomol. Soc. 62, 400-410

63 Rozen, J.G. and Ruz, L. (1995) South American Panurgine bees (Andrenidae: Panurginae), part II. Adults, immature stages, and biology of Neffapis longilingua, a new genus and species with an elongate glossa. Am. Mus. Novit. 3136, 1-15

64 Neff, J.L. (2003) The passiflower bee: Anthemurgus passiflorae. Passiflora 13, 7-9

65 González-Varo, J.P., Ortiz-Sánchez, F.J. and Vilà, M. (2016) Total bee dependence on one flower species despite available congeners of similar floral shape. PLOS ONE 11, e0163122 https://doi.org/10.1371/journal.pone.0163122

66 Mayr, E. (1960) The emergence of evolutionary novelties. In Evolution After Darwin (Tax, S., ed.), pp. 349-380, University of Chicago Press, Chicago

67 Linsley, E.G. (1962) Ethological adaptations of solitary bees for the pollination of desert plants. In Proceedings of the First International Symposium on Pollination (Mittler, T.E., ed.), pp. 189-197, Swedish Seed Growers Association, Copenhagen, Denmark

68 Thorp, R.W. (1979) Structural, behavioral, and physiological adaptations of bees (Apoidea) for collecting pollen. Ann. Mo. Bot. Gard. 66, 788-812 https://doi.org/10.2307/2398919

69 Buchmann, S.L. (1985) Bees use vibration to aid pollen collection from non-poricidal flowers. J. Kans. Entomol. Soc. 58, 517-525

70 Dedej, S. and Delaplane, K.S. (2003) Honey bee (Hymenoptera: Apidae) pollination of rabbiteye blueberry Vaccinium ashei var. 'Climax' is pollinator density-dependent. J. Econ. Entomol. 96, 1215-1220 https://doi.org/10.1603/0022-0493-96.4.1215

71 Gogala, A. and Surina, B. (2011) Foraging behaviour of the bee Osmia apicata Smith, 1853 (Hymenoptera: Megachilidae). Acta Entomol. Slovenica 19, 139-144

72 Dukas, R. and Dafni, A. (1990) Buzz-pollination in three nectariferous Boraginaceae and possible evolution of buzz-pollinated flowers. Plant Syst. Evol. 169, 65-68 https://doi.org/10.1007/BF00935985

73 Torchio, P.F. (1990) Osmia ribifloris, a native bee species developed as a commercially managed pollinator of highbush blueberry (Hymenoptera: Megachilidae). J. Kans. Entomol. Soc. 63, 427-436 
74 Cane, J.H. (2014) The oligolectic bee Osmia brevis sonicates Penstemon flowers for pollen: a newly documented behavior for the Megachilidae. Apidologie 45, 678-684 https://doi.org/10.1007/s13592-014-0286-1

75 Cardinal, S., Buchmann, S.L. and Russell, A.L. (2018) The evolution of floral sonication, a pollen foraging behavior used by bees (Anthophila). Evolution 72, 590-600 https://doi.org/10.1111/evo.13446

76 Rozen, J.G. and Ugarte-Peña, A. (1999) Notes on the seasonality, geographic distribution, and floral preferences of the bee Alocandrena porteri (Hymenoptera: Andrenidae). J. Kans. Entomol. Soc. 72, 335-338

77 Hegland, S.J., Nielsen, A., Lázaro, A., Bjerknes, A.-L. and Totland, Ø. (2009) How does climate warming affect plant-pollinator interactions? Ecol. Lett. 12, 184-195 https://doi.org/10.1111/j.1461-0248.2008.01269.x

78 Schenk, M., Krauss, J. and Holzschuh, A. (2018) Desynchronizations in bee-plant interactions cause severe fitness losses in solitary bees. J. Anim. Ecol. 87, 139-149 https://doi.org/10.1111/1365-2656.12694

79 Riveros, A.J., Hernández, E.J. and Wcislo, W.T. (2009) Nesting biology of Euglossa dodsoni Moure (Hymenoptera: Euglossinae) in Panama. J. Kans. Entomol. Soc. 82, 210-214 https://doi.org/10.2317/JkES808.15.1

80 Bronstein, J.L., Gouyon, P.-H., Gliddon, C., Kjellberg, F. and Michaloud, G. (1990) The ecological consequences of flowering asynchrony in monoecious figs: a simulation study. Biol. J. Linn. Soc. 71, 2145-2156

81 Robbirt, K.M., Roberts, D.L., Hutchings, M.J. and Davy, A.J. (2014) Potential disruption of pollination in a sexually deceptive orchid by climatic change. Curr. Biol. 24, 2845-2849 https://doi.org/10.1016/j.cub.2014.10.033

82 Kehrberger, S. and Holzschuh, A. (2019) Warmer temperatures advance flowering in a spring plant more strongly than emergence of two solitary spring bee species. PLoS ONE 14, e0218824 https://doi.org/10.1371/journal.pone.0218824

83 Miller-Struttmann, N.E., Geib, J.C., Franklin, J.D., Kevan, P.G., Holdo, R.M., Ebert-May, D. et al. (2015) Functional mismatch in a bumble bee pollination mutualism under climate change. Science 349, 1541-1544 https://doi.org/10.1126/science.aab0868

84 Schmidt, N.M., Mosbacher, J.B., Nielsen, P.S., Rasmussen, C., Høye, T.T. and Roslin, T. (2016) An ecological function in crisis? - the temporal overlap between plant flowering and pollinator function shrinks as the Arctic warms. Ecography 39, 1250-1252 https://doi.org/10.1111/ecog.02261

85 Ferrari, R.R. (2015) A new species of Geodiscelis Michener \& Rozen (Hymenoptera: Colletidae: Xeromelissinae) from Peru. Zootaxa 4033, 293-300 https://doi.org/10.11646/zootaxa.4033.2.10

86 Engel, M.S. (2000) Classification of the bee tribe Augochlorini (Hymenoptera: Halictidae). Bull. Am. Mus. Nat. Hist. 250, 1-89 https://doi.org/10.1206/ 0003-0090(2000)250<0001:COTBTA>2.0.C0;2

87 Michener, C.D. (1999) The corbiculae of bees. Apidologie 30, 67-74 https://doi.org/10.1051/apido:19990108

88 Braue, A. (1913) Die Pollensammelapparate der beinsammelnden Bienen. Jenaische Zeitschrift für Naturwissenschaft. 50, 1-96

89 Engel, M.S. (2001) A monograph of the Baltic amber bees and evolution of the Apoidea (Hymenoptera). Bull. Am. Mus. Nat. Hist. 259, 1-192 https://doi.org/10.1206/0003-0090(2001)259<0001:AMOTBA>2.0.C0;2

90 Hesse, M., Halbritter, H., Zetter, R., Weber, M., Buchner, R., Frosch-Radivo, A. et al. (2009) Pollen Terminology: An Illustrated Handbook, Springer, Wien

91 Eardley, C.D. (1989) The Afrotropical species of Eucera Friese, Tetralonia Spinola and Tetraloniella Ashmead (Hymenoptera: Anthophoridae). Entomol. Mem. Department of Agriculture and Water Supply 75, 1-62

92 Engel, M.S., Alquarni, A.S. and Shebl, M.A. (2017) Discovery of the bee tribe Tarsaliini in Arabia (Hymenoptera: Apidae), with the description of a new species. Am. Mus. Novit. 3877, 1-28 https://doi.org/10.1206/3877.1

93 Roberts, R.B. and Vallespir, S.R. (1978) Specialization of hairs bearing pollen and oil on the legs of bees (Apoidea: Hymenoptera). Ann. Entomol. Soc. Am. 71, 619-627 https://doi.org/10.1093/aesa/71.4.619

94 Robertson, C. (1925) Heterotropic bees. Ecology 6, 412-436 https://doi.org/10.2307/1929107

95 Neff, J.L. (2004) Hooked hairs and not so narrow tubes: Two new species of Colletes Latreille from Texas (Hymenoptera: Apoidea: Colletidae). J. Hymenopt. Res. 13, 250-261

96 Müller, A. (1996) Convergent evolution of morphological specializations in Central European bee and honey wasp species as an adaptation to the uptake of pollen from nototribic flowers (Hymenoptera, Apoidea and Masaridae). Biol. J. Linn. Soc. 57, 235-252 https://doi.org/10.1006/bijl.1996.0013

97 Parker, F.D. and Tepedino, V.J. (1982) A nest and pollen-collection records of Osmia sculleni Sandhouse, a bee with hooked hairs on the mouthparts (Hymenoptera: Megachilidae). J. Kans. Entomol. Soc. 55, 329-334

98 Thorp, R.W. (2000) The collection of pollen by bees. Plant Syst. Evol. 222, 211-223 https://doi.org/10.1007/BF00984103

99 Alves-dos-Santos, I. (2003) Adaptations of bee proboscides for collecting pollen from Pontederiaceae flowers. In Apoidea Neotropica: Homenagem aos 90 Anos de Jesus Santiago Moure (Melo, G.A.R. and Alves-dos-Santos, I., eds), pp. 257-264, Editora UNESC, Criciúma

100 Vogel, S. (1969) Flowers offering fatty oil instead of nectar. XI Int. Bot. Congr. Abstr. 1969, 229

101 Rasmussen, C. and Olesen, J.M. (2000) Oil flowers and oil-collecting bees. Det Norske Videnskaps-akademi I Matematisk Naturvidenskapelig Klasse, Skrifter. Ny Serie 39, 23-31

102 Vogel, S. (1988) Die ölblumensymbiosen - Parallelismus und andere Aspekte ihrer Entwicklung in Raum und Zeit. Z. Zool. Syst. Evol. forsch. 26 341-362 https://doi.org/10.1111/j.1439-0469.1988.tb00322.x

103 Steiner, K.E. and Whitehead, V.B. (1988) The association between oil-producing flowers and oil-collecting bees in the Drakensberg of Southern Africa. Monogr. Syst. Bot. Mo. Bot. Gard. 25, 259-277

104 Neff, J.L. and Simpson, B.B. (1981) Oil-collecting structures in the Anthophoridae (Hymenoptera): morphology, function, and use in systematics. J. Kans. Entomol. Soc. 54, 95-123

105 Buchmann, S.L. (1987) The ecology of oil flowers and their bees. Annu. Rev. Ecol. Syst. 18, 343-369 https://doi.org/10.1146/annurev.es.18.110187. 002015

106 Roig-Alsina, A. (1997) A generic study of the bees of the tribe Tapinotaspidini, with notes on the evolution of their oil-collecting structures. Mitt. Münch. Ent. Ges. 87, 3-21 